\title{
Medical application of exopolymers produced by marine bacteria
}

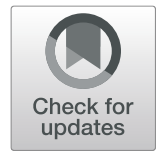

\author{
Sayeda A. Abdelhamid", Sahar S. Mohamed and Manal S. Selim
}

\begin{abstract}
Background: Natural products have been viewed as essential sources that could create potential chemotherapeutic agents. In the look for new bioactive substances, examinations were extended to marine territories.

Results: Humanity has known for the last few thousand years that a marine organism contains substances fit for strong biological activity. However, the main genuine examination of marine living beings began just 50 years prior. Since then, all types of life in the marine condition (e.g., bacteria, algae, and fungi) have been researched for their bioactive content.
\end{abstract}

Conclusions: Exopolymers can be applied in a wide range of industrial applications in biomedicines.

Keywords: Exopolymers, Marine bacteria, Bioactive substances

\section{Introduction}

It was recently found that over a long period of time, plants, animals and microorganisms from the marine condition have uncovered a part of what is obviously a huge source of bioactive metabolites. Among other natural sources, the marine biological system is progressively being recognized as a wellspring of potential natural product (Abad et al. 2011; De Jesus Raposo et al. 2014; Devesh et al. 2017; Wang et al. 2018).

An exopolymer is a biopolymer that is secreted by an organism into the environment (i.e., external to the organism). These exopolymers include the biofilms produced by bacteria to anchor them and protect them from environmental conditions (Flemming et al. 2004; Dupraz and Visscher, 2005). Most exopolymers consist of polysaccharides (exopolysaccharides) and proteins, may also include other molecules such as DNA, lipids, and humic substances (Aguilar et al. 2007; Braissant et al. 2009).

EPS is a sugar polymer mainly produced by bacteria and microalgae, in two forms as capsular polysaccharide (CPS) which is bound to the cell wall or slime EPS which is liberated into the culture medium (Sutherland 1972; Cao et al.
2019). The classification and chemistry of bacterial EPS are scheduled in Table 1. It was known that EPS is the main line of biological defense against different attacks and physical stresses (Whitfield 1988; Roberts 1996; Looijesteijn et al. 2001; Paolucci et al. 2015). Based on structural structure, EPS can be microbial. They are classified into three groups, homo-polysaccharide, hetero-EPS, and polysaccharides with irregular structures (Jin et al. 2010; DelbarreLadrat et al. 2014).

Moreover, EPS additionally have appeared with wide scope of different applications, for example, emulsification, thickness, absorption, film development, gel arrangement, and anticancer treatment (Lee et al. 2001; Ohno et al. 2001; Ke et al. 2009; Thomas and Kim, 2013; Yahya et al. 2019). EPS have great biological activity and assume jobs in the control of cell division and differentiation, immune regulation, and additionally have antitumor, antioxidant, and antiviral activities. Due to the antioxidant activity of EPS, it prevents different diseases, inflammation, and atherosclerosis (Lu et al. 2000; Zhang et al. 2003; De Jesus Raposo et al. 2015; Asker et al. 2015).

\footnotetext{
* Correspondence: sayeda.abdelrazek@yahoo.com

Microbial Biotechnology Department, National Research Centre, Cairo, Egypt
}

Springer Open
๑ The Author(s). 2020 Open Access This article is licensed under a Creative Commons Attribution 4.0 International License, which permits use, sharing, adaptation, distribution and reproduction in any medium or format, as long as you give appropriate credit to the original author(s) and the source, provide a link to the Creative Commons licence, and indicate if changes were made. The images or other third party material in this article are included in the article's Creative Commons licence, unless indicated otherwise in a credit line to the material. If material is not included in the article's Creative Commons licence and your intended use is not permitted by statutory regulation or exceeds the permitted use, you will need to obtain permission directly from the copyright holder. To view a copy of this licence, visit http://creativecommons.org/licenses/by/4.0/. 
Table 1 Some roles of microbial exopolymeric material (EPS) in the marine environment (El-Raheem El-Helw and El-Said, 1988)

\begin{tabular}{|c|c|}
\hline Role of Exopolymer & Example \\
\hline Assists in attachment to surfaces & $\begin{array}{l}\text { Exopolymers of manine Vibrio MH3 were involved in } \\
\text { reversible attachment. } \\
\text { Cross-linking of adjacent polysacchande chains aided in } \\
\text { permanent adhesion. }\end{array}$ \\
\hline $\begin{array}{l}\text { Facilitates biochemical interactions } \\
\text { between cells }\end{array}$ & $\begin{array}{l}\text { Exopolymer mediated bactenal attachment to the polar } \\
\text { end of blue-green } \mathrm{N}_{2} \text {-fixing alga. EPS aided attachment } \\
\text { to symbiotic bost such as vent tube worm to absorb } \\
\text { metals and detoxify microenvironment. } \\
\text { Exopolymer buffered against sudden osmotic changes. }\end{array}$ \\
\hline Provides protective barrier around the cell & $\begin{array}{l}\text { Bactena in aggegates were less prefened by gazzers than } \\
\text { freely suspended bacteria. } \\
\text { EPS-producing deep-sea hydrotbermal vent bactena } \\
\text { showred resistance to heavy metals. Metal binding } \\
\text { involves cell wall components as well as polysacchandes. } \\
\text { Exopolymer in sea-ice brine channels provided } \\
\text { cyoprotection by interacting with water at low } \\
\text { temperature to depress freezing point. } \\
\text { Nuthent uptake by bactena in aggregates was higher than } \\
\text { for free-living cells in low nuthent systems. }\end{array}$ \\
\hline Absorbs dissolved organic material & $\begin{array}{l}\text { Porous and hydrated matix acts like a sponge and } \\
\text { sequesters and concentrates dissolved organics. }\end{array}$ \\
\hline
\end{tabular}

\section{Marine floras}

Marine floras incorporate microflora and blossoming plants. Possessing relatively $71 \%$ of the globe, the sea is wealthy in biodiversity, and the microflora and microalgae alone establish over $90 \%$ of maritime biomass (DeVugst and Vandamme 1994; Kathiresan and Duraisamy 2005; Kathiresan and Thiruneelakandan 2008; Nadia et al. 2016). This tremendous marine floral resource will offer an incredible breadth for revelation of new medications. The marine floras are wealthy in therapeutically powerful chemicals having a place with polyphenols and sulfated polysaccharides (Haefner 2003; Mayer and Lehmann 2004; Xu et al. 2011; Cao et al. 2019). Marine condition offers a huge biodiversity, and polysaccharides have been found displaying an incredible synthetic variety that is to a great extent species specific. The investigation of the 
natural properties of the polysaccharides from marine eukaryotes and marine prokaryotes revealed that the polysaccharides from the marine condition could be alternative for customary polysaccharides, for example, glycosaminoglycans. Marine EPS present a genuine potential for natural bioactive drugs used in medical applications (Martins et al. 2014; Devesh et al. 2017 and Elsakhawy et al. 2017).

Marine microorganisms are a wellspring of new genes (Table 1), and it is probably going to prompt the revelation of new medications and targets. EPS produced by marine microbes have yielded pharmaceutical items, for example, novel anti-inflammatory agents, such as pseudopterosins, topsentins, scytonemin, and manoalide; anticancer agents (e.g., bryostatins, discodermolide, eleutherobin, and sarcodictyin); and anti-microbials (e.g., marinone). The use of probiotic microscopic organisms, i.e., bacteria, for example, lactobacilli and Bifidobacteria, is for the most part in the control of pathogenic microorganisms, through generation of antibacterial protein to be specific, bacteriocin (DeVugst and Vandamme 1994; Kathiresan and Thiruneelakandan 2008) and anticancer substances (Wollowski et al. 2001; Meera et al. 2011; Yahya et al. 2019). The dietary enhancements of lactobacilli are purportedly diminishing the induction of colon cancer (Goldin and Gorbach 1992; Wu and Chen 2006; Selim et al. 2018 a). EPS from marine microorganisms are important to new medication revelation (Han et al. 2005; Miranda et al. 2008; Xu et al. 2009; Diao et al. 2014; Selim et al. 2018 b).

\section{Bacterial exopolysaccharides (EPS)}

Bacteria have been producing several polysaccharide (Tables 2 and 3). Screenings have been performed basically on mesophilic microorganisms as opposed to on psychrophilic, thermophilic, or hyperthermophilic strains. Up to date, three principle genera of polysaccharide-delivering microorganisms have been distinguished: Pseudoalteromonas sp., Alteromonas sp. also, Vibrio sp. during fermentation, every bacterium can free into the medium (an oxygenconsuming sugar-based medium), one explicit EPS with a unique structure and with an intriguing yield, from 0.5 to 4 g of polysaccharide/liter of culture stock (Guezennec 2002; Raza et al. 2011). The Vibrio diabolicus bacterium was secluded from a Pompeii worm tube (polychaete Alvinella pompejana); the EPS it emitted was portrayed by equivalent measures of glucuronic acid and hexosamine ( $\mathrm{N}$-acetyl glucosamine and $\mathrm{N}$-acetyl galactosamine). It is a hyaluronic acid-like polymer (Fig. 1) (Raguenes et al. 1997; Rougeaux et al. 1999; Arias et al. 2003) and its name is Hyalurift.

\section{Pharmacological applications of polysaccharides}

During the previous three decades, numerous polysaccharides and polysaccharide protein complexes have been secluded from mushrooms, parasites, yeasts, green growth, lichens, and plants with therapeutic properties. Bacterial growth is regularly joined by the creation of EPSs (Table 4), which have essential biological and physiological functions. Due to EPS' immunomodulatory and antitumor impacts, they have more consideration in the biochemical and restorative fields. The capacity of bioactive polysaccharides and polysaccharide-bound proteins in immune functions might be because of the basic structural diversity and variability of these macromolecules. A fruitful methodology in malignant growth treatment is to trigger apoptosis yet usually confounded by improvement of multi drug resistance (MDR) mechanisms (Salgaller and Hotel 1998). EPS can down direct P-glycoprotein and reverse MDR (De Vuyst and Degeest 1999; Ooi and Liu 2000; Laws et al. 2001; Wei et al. 2008 and Kambourova et al. 2009). Bioactive compounds have been the pillar of disease chemotherapy for as long as 30 years and are probably going to give a significant number of the lead structures, and these will be utilized as formats for the development of novel compounds with improved biological properties (John 2002; Poli et al. 2010; Donato et al. 2016; Elsakhawy et al., 2017; Yahya et al. 2019).

\section{Characteristics of exopolymers as antioxidant activity}

The oxidative stress, characterized as the imbalance among oxidants and antioxidants for the oxidants potentially prompting harm, has been proposed to be what cause aging and different illnesses in people. In present day western prescription, the harmony among antioxidation and oxidation is accepted to be a basic idea of keeping up a healthy biological system (Dreosti 1991; Ahmad 1995; Davies 2000; Tiwari 2001; Katalinic et al. 2006; $\mathrm{Hu}$ et al. 2011). Physiologically, antioxidants assume a noteworthy job in keeping the arrangement of free radicals, which are in charge of numerous oxidative procedures; antioxidants might be engineered or of normal source (Hu et al. 2001; Abas et al. 2006; Asker et al. 2010; Chen et al. 2011).

Free radicals can respond with biomolecules, making broad harm to DNA, protein, and lipid, which are viewed as identified with aging (Oliveira et al. 2010), degenerative maladies of maturing (Gey, 1990; Oberley, 2002), and malignant growth (Sangeetha et al. 1990). Free radicals and reactive oxygen species (ROS) assume vital physiological jobs; they are basic for generation of energy, combination of biologically essential compounds, and phagocytosis, a basic procedure of immune system. They additionally assume a fundamental job in signal transduction. There is additionally expanding proof that these ROS may assume a causative job in an assortment of illnesses including coronary illness, atherosclerosis, 
Table 2 Some exopolysaccharides producing marine bacteria

\begin{tabular}{||ll||}
\hline \multicolumn{1}{|c}{$\cdot$ - } & - \\
\hline Marine bacteria & Sources \\
\hline Planococcus maitriensis Anita I & Coastal sea water of Bhavnagar \\
S. degradans & District, India \\
Vibrio furmissii strain VB0S3 & - \\
Enterobacter cloacae & Coastal region of Goa \\
Halomonas spp. & Marine sediments \\
Halomonas anticariensis & - \\
Halomonas ventosae & - \\
Alteromonas haloplanktis KMM 156 & - \\
Alteromonas infernus (A. infemus) & Deep sea hydrothermal vent \\
Alteromonas macleodii 2MM6 & Intertidal zone of Halifax, Nova \\
& Scotia \\
Bacillus licheniformis (B. & Volcano island \\
licheniformis) & \\
Bacillus marinus & Marine sediment \\
Bacillus strain B3-15 & Shallow water, marine hot spring \\
Bacillus strain B3-72 & Shallow vent \\
Bacillus thermoantarcticus & Ischia island \\
Geobacillus sp. & - \\
Desulfovibrio sp. strain Indl & Indonesian coast \\
Flavobacterium uliginosum & - \\
Hahella chejuensis & - \\
Pantoea sp. BM39 & Seafloor sediments \\
Pseudoalteromonas atlantica & - \\
Pseudoalteromonas sp. strain S9 & Marine sediment \\
Pseudomonas sp strain NCMB 2021 & Madilyn fletche Halifax, Nova \\
\hline
\end{tabular}

and cancer (Liu et al. 1997; Mau et al. 2002; Blander et al. 2003; Asker and Shawky 2010).

Free radicals and ROS assault lipids, sugars, proteins, and DNA and initiate their oxidation, which might result in oxidative harm, for example, membrane dysfunction, protein modification, enzyme inactivation, and breakage of DNA strands and modification of its bases. In spite of the fact that all life forms have antioxidant defense and 
Table 3 Sugar and non-sugar components of bacterial exopolysaccharides (El-Raheem El-Helw and El-Said, 1998)

\begin{tabular}{llll}
\hline Type & Component & Example & Mode of Linkage \\
\hline Sugar & Pentoses & D-Arabinose & \\
& & D-Ribose & \\
& & D-Xylose & \\
& Hexoses & D-Glucose & \\
& & D-Mannose & \\
& & D-Galactose & \\
& & D-Allose & \\
& & L-Ramnose & \\
& & L-Fucose & \\
& Amino sugars & D-Glucosamine & \\
& D-Galactosamine & \\
& Uronic acids & D-Glucuronic acid & O-acyl, $N$-acyl \\
& & D-Galacturonic acid & O-acyl \\
& Acetic acid & & Acetal \\
& Succinic acid & & Ester, Diester \\
& Pyruvic acid & & Ester \\
\hline
\end{tabular}

fix systems to secure against oxidative damage, these systems are regularly lacking to keep the harm totally (Moskovitz et al. 2002).

Antioxidants assume a vital job in the later phases of malignancy improvement. There is expanding proof that oxidative processes advance carcinogenesis, despite the fact that the mechanisms for this are not surely known. The antioxidants might have the capacity to cause the relapse of premalignant lesions and hinder their advancement into cancer (Langseth 1995; Hobbs 2000; Liu et al. 2009; Hu et al. 2010). Probiotic microorganisms synthesize (EPSs) with commercially noteworthy physiological and medical activities. This essential class of biomolecules is additionally portrayed by their capacity to expel ROS that are framed in the digestive tract by different metabolic responses; henceforth, they display antioxidant activities. The probiotic bacterium, Bacillus coagulans RK-02, produces an EPS in the exponential and stationary development stages when grown

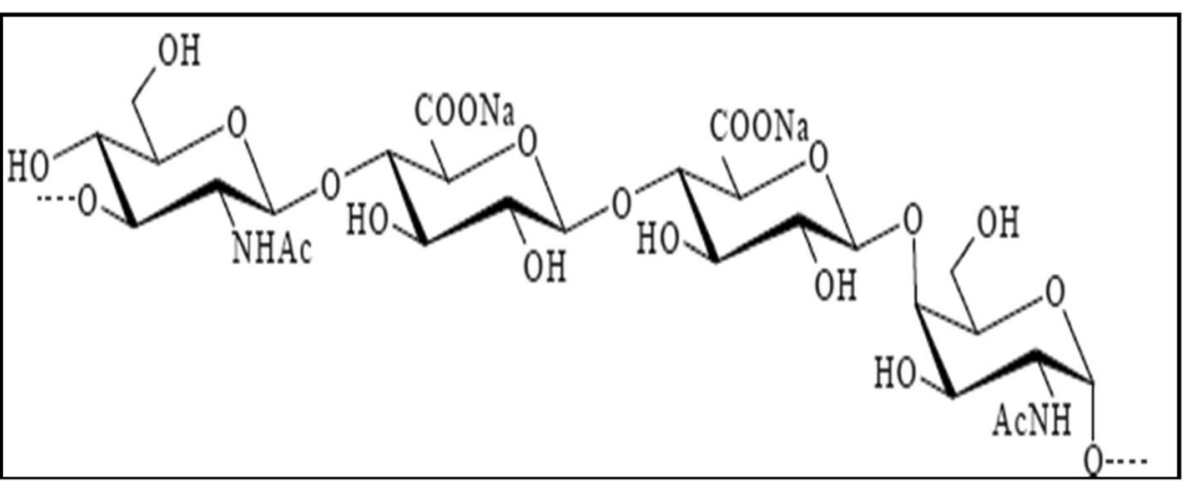

Fig. 1 Repeating unit of the marine bacterial polysaccharide (HE800 EPS) produced by Vibrio diabolicus 
Table 4 Some potential biotechnological applications of marine bacterial EPS

\begin{tabular}{|ll|}
\hline Marine bacteria & Biotechnological applications \\
\hline A. infernus strain GY785 & Anticoagulant activity, increased the viability and pro \\
engineering
\end{tabular}

in a glucose mineral salt medium. The antioxidant and free radical scavenging capability of produced EPS were assayed by different assays. The outcomes demonstrated that the EPS, which is a heteropolymer made out of four monosaccharides, delivered by B. coagulans RK-02 had noteworthy antioxidant activity (Kodali and Sen 2008; Ye et al. 2009; Yan et al. 2011; Selim et al. 2015).

Cancer stays as a driving reason for death, all inclusive. IARC (2010) as of late assessed that 7.6 million passing around the world, because of cancer with 12.7 million new cases for each year were being accounted for around the world. A noteworthy extent of this weight is borne by developing countries; $63 \%$ of malignant growth passings are accounted for to be from developing countries. Cancer is a multigenic and multicellular malady that can emerge from all cell types and organs with a multi-factorial etiology (Liu et al. 2005; Ferlay et al. 2010; Yan et al. 2010; Jemal et al. 2011). The clinical treatment techniques against cancer include the following: medical procedure, which is neighborhood extraction of tumor; radiotherapy, which dispense with tumor by presenting to radiation; chemotherapy, which depends on medication focusing on tumor cells; joined methodology treatment, which incorporates each of the three previous medicines together; and immunotherapy, which summons a safe reaction against tumor. Most tumor medications bring about symptoms like complexities and toxicity; along these lines, patients need to experience the ill effects of the agony of medicines (Borchers et al. 1999; Funahashi et al. 2001; Shibata et al. 2002; Allen 2002; Yamasaki et al. 2012).

A definitive explanation behind the suffering underlies in the comparability between tumor cells and normal cells. It is important to discover a treatment that could take out cancer cells while shielding ordinary cells from being slaughtered (Miller et al. 1981; Matsuda et al. 2003; Pang et al. 2007; Pangestuti and Kim 2011; Yahya et al. 2019). The capacity of bioactive EPS and polysaccharide bound proteins to balance such a large number of vital immune functions might be because of the basic 
structural diversity and variability of these molecules. An effective methodology in malignant growth treatment is to trigger apoptosis; however, this is usually entangled by advancement of multi-drug resistance (MDR) mechanisms (Salgaller and Cabin 1998). EPS can down direct P-glycoprotein, and invert MDR (De Vuyst and Degeest 1999; Ooi and Liu 2000; Laws et al. 2001; Wei et al. 2008; Kambourova et al. 2009).

Bacterial EPS have great biological activity and assume jobs in the control of cell division and separation, immune regulation, and additionally have antitumor, antioxidant, and antiviral activities (Zhang et al. 2003; Selim et al., 2018a, b).

Umezawa et al. (1983) screened EPS of marine microorganisms for their anticancer activity against sarcoma180 strong tumor in mice. Lactic acid bacteria (LAB) for example, Lactobacillus, are imperative microorganisms in healthy human microbiotic environment (Macfarlane and Cummings 2002). LAB are useful bacteria, which have been related with a few probiotic impacts in both people and animals (Fuller 1989; Yang et al. 2001; Iwai et al. 2004). Various reports have shown that both LAB and milk exert apply anticancer impacts (Biffi et al. 1997; Lee et al. 2004). Information from epidemiological and exploratory examinations have likewise shown that the ingestion of certain LAB strains, or of milk exert, may reduce the danger of particular sort of malignant growths and repress the development of tumors (Kato et al. 1994). Be that as it may, the exact component by which LAB applies anticancer impacts stays obscure. Enterobacter cloacae Z0206, a bacterial strain, can create a lot of EPSs. It has been accounted for that glycoproteins from $E$. cloacae demonstrated antitumor consequences for mice with S180 tumors (real), and F3, one of the glycoprotein parts, could particularly restrain QGY7703 (liver malignant growth), A549 (glandular cancer of the lungs), Kato III (gastric carcinoma), and Sw1116 (intestinal cancer) cell strains (Zhang et al. 2002).

Ruiz-Ruiz et al. (2011) demonstrated that the novel halophilic bacterium Halomonas stenophila strain B100 emits EPSs with high sulfate substance. This hetero-EPS when over sulfated applied anticancer activity on $\mathrm{T}$ cell lines getting from acute lymphoblastic leukemia (ALL). Just tumor cells were vulnerable to apoptosis actuated by the sulfated EPS (B100S), while essential immune system cells were safe. In addition, naturally detached essential cells from the blood of patients with ALL were additionally susceptible to B100S-induced apoptosis. EPS are presently drawing in more prominent consideration inside the field of medicine. This is on the grounds that the EPS have various impacts that incorporate the capacity to animate $\mathrm{T}$-cell formation and potentiate the induction of various sorts of antitumor effector cells, for example, cytotoxic T-cells, NK cells and macrophages
(Wasser and Weis 1999). Numerous immunostimulating PS likewise have antitumor properties (Borchers et al. 1999; Ikewa 2001). PS with antitumor activity have different chemical compositions, configurations, and also in their physical properties. Antitumor activity is shown by a wide scope of glycans reaching out from homopolymers to very unpredictable heteropolymers (Ooi and Liu 1999). The difference of EPS activity can be related with dissolvability in water, size of the particles, branching rate, and form.

Mechanisms announced for the anticarcinogenic effects incorporate (i) hindrance of cancer induction (Reddy et al. 1984), (ii) restraint of hyaluronidase activity (Shibata et al. 2002), (iii) anti-inflammatory, (iv) antiproliferative activities (Berge et al. 2002), (v) control of mammary organ uprightness (Aceves et al. 2005), (vi) antioxidative (Eskin et al. 1995), (vii) apoptosis induction (Kwon and Nam 2006; Yamasaki et al. 2009) through the expression of transforming growth factor (TGF-b), (Funahashi et al. 2001), (viii) concealment of tumor inception VEGF165 (vascular endothelial growth factor 165 ) binding to its cell surface receptors (Dias et al. 2008; Satoru et al. 2003; Ye et al. 2005; Yumi et al. 2009), (ix) restraint of tumor cells intrusion (Ye et al. 2005), (x) immune response enhancement (Itoh et al. 1995), (xi) SOD activity hindrance (Funahashi et al. 2001), and (xii) estrogen generation concealment. The present understanding of the anticancer and immunomodulating impacts of EPSs are as per the following: (1) coordinate hindrance of development of different sorts of malignant cells; (2) immunostimulating activity against tumors in combination with chemotherapy; (3) preventive impact on spreading or relocation of malignancy cells in the body (Wasser 2002; Moradali et al. 2007; Martins et al. 2014) (Fig. 2a). Figure 2 b illustrates the mechanism of action in the drug activity marine PSs (anti-inflammatory effect and immune modulation effect).

\section{Antiviral activity}

$\mathrm{Li}$ et al. (1995) showed that sulfated EPS (counting fucoidan) displayed antiviral activities both in vivo and in vitro, with low cytotoxicity contrasted with other antiviral medications right now utilized in clinical medicine. Fucoidan of Laminaria japonica has anti RNA and DNA virus functions. The antivirus impacts of fucoidan because of poliovirus III, adenovirus III, ECHO6 infection, coxsackie B3 infection, and coxsackie A16 are surprising. Fucoidan can restrain the improvement of cytopathic impact (CPE) and shield social cells from contamination caused by above infections. The sulfated EPS are known to interfere with the absorption and penetration of infections into host cell and to restrain different retroviral reverse transcriptases (Masuda et al. 1999; De Clercq 

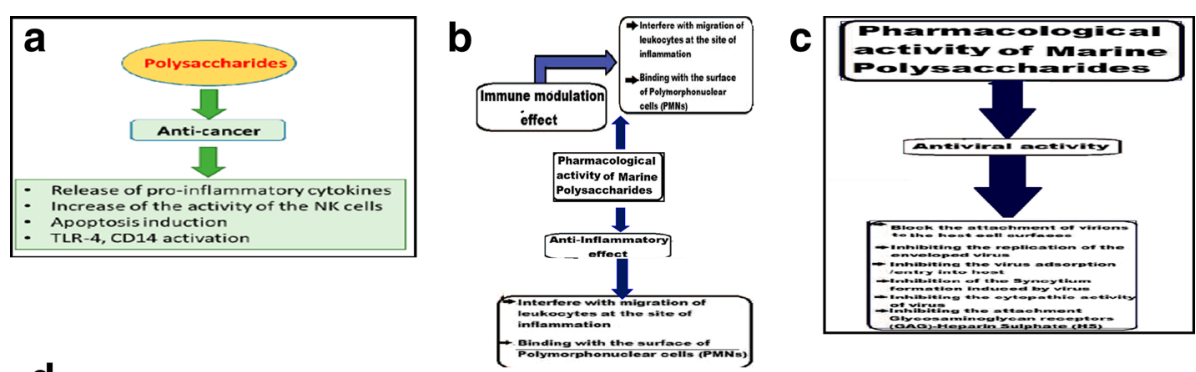

d

e
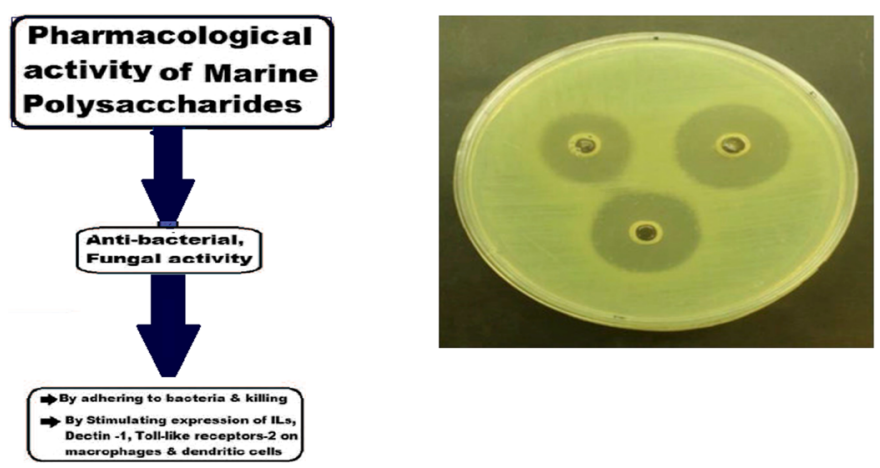

Fig. 2 a Properties of marine polysaccharides and their applications in pharmacology (as anticancer). $\mathbf{b}$ the mechanism of action in the drug activity marine PSs (anti-inflammatory effect and immune modulation). c Properties of marine polysaccharides and their applications in pharmacology (as anti-viral). d Properties of marine polysaccharides and their applications in pharmacology (as Antimicrobial). e Inhibition zone of different concentration of EPS against Escherichia coli

2004; Senel and McClure 2004; Seng et al. 2008; Hayashi et al. 2008).

Research on bioactive compound having antiviral activity is essentially centered around low-molecularweight compounds disengaged from plants since they can be chosen based on their ethno-therapeutic use (Kinghorn 2001). The primary report of the antiviral activity of molecular-weight PS showed up very nearly 60 years prior by Ginsberg et al. (1947). After 17 years, Nahmias and Kibrick (1964) exhibited that heparin can go about as inhibitors of herpes simplex infection (HSV). Various sulfated EPS from marine bacteria, cyanobacteria, and green algae were depicted appearing inhibitory impacts against a few human and animal viruses (Luescher-Mattli 2003; Damonte et al. 2004; Arad et al. 2006). Sulfated PS of synthetic origin has antiviral activity (Witvrouw and De Clercq 1997). A portion of these macromolecules are now experiencing clinical assessment (Kleymann 2005; McReynolds and GarveyHague 2007). They have a promising point of view to be developed into a novel kind of antiviral medications. The antiviral activities are depending on the degree of sulfation, furthermore molecular weight (Hemmingson et al. 2006). Sulfated PS may hinder the connection of viruses with target particles on the cell surface (Ponce et al. 2003; Pilar et al. 2005).
The viral connection peptides are very saved areas inside rather than factor platforms of viral surface glycoproteins. These peptides are just inadequately subject to adjustments by the common antigenic drift of viruses. Moreover, they are not expected to visit locales of medication-incited resistance mutation. Sulfated PS that is coordinated toward these objective peptides are in this manner favored possibility for antiviral medication improvement. Also, sulfated polymers appeared in vitro antiviral action against mutants resistant to nucleoside analogs (Adhikaria et al. 2006; Mandal et al. 2007).

Arena et al. (2009) revealed the antiviral and the immunoregulatory impact of another EPS (EPS-2) from a thermotolerant Bacillus licheniformis secluded from a shallow vent of Vulcano Island (Italy). EPS seemed to enhance immune surveillance of human peripheral blood mononuclear cells (PBMC) toward HSV-2 (herpes simplex infection) disease by setting off the generation of Th1-type cytokines. The treatment of PBMC with EPS-2 at higher doses (300 and $200 \mu \mathrm{g} / \mathrm{ml}$ ) incites the arrival of a more prominent measure of Th1 cytokines. As an outcome, the advancement of a cytokine coordinate with a net genius provocative impact, identified with expanded protection from viral replication, can be theorized. The treatment of PBMC with $100 \mu \mathrm{g} / \mathrm{ml}$ of EPS-2 did not block HSV-2 replication but rather was as yet 
ready to trigger infected $\mathrm{PBMC}$ to discharge some type 1 cytokine, for example, TNF- $\alpha$ and IL-18, and also obvious measures of IL-4 and IL-10 (Fig. 2c).

\section{Antimicrobial activity}

Nguyen et al. (2008) built up a bacterially produced EPS (cellulose), containing nisin so as to control Listeria monocytogenes in foodstuff. Bacterial EPS was created by Gluconacetobacter xylinus K3. Nisin $(2500 \mathrm{IU} / \mathrm{mL})$ was joined into the polymer matrix. EPS decreased L. monocytogenes populaces on foodstuff of around $2 \log$ CFU/g following 14 days of storage.

Orsod et al. (2012) isolated two EPS from marine bacteria and screened their activities against Lysinibacillus and Paenibacillus sp. which represent Gram-positive bacteria and (Pseudomonas sp., Escherichia coli) as Gram-negative bacteria. The produced EPSs showed antimicrobial activities against all the tested organisms.

Some studies exhibited the adequacy of lentinan administrated intraperitoneally before infection of Mycobacterium tuberculosis. The outcomes proposed that lentinan could assemble, have protection potential, and diminish Mycobacterium disease (Markova et al. 2003). Another exploration exhibited that lentinan prompted abnormal state of alveolar macrophage enactment showed through improved bactericidal impact against $M$. tuberculosis, which corresponded with the induction of responsive nitrogen intermediates, expanded movement of lysosomal enzymes (acid phosphates), and with powerful phagolysosomal combination pursued by decimation of Mycobacterium (Markova et al. 2005; Shanmugam et al. 2008; He et al. 2010) (Fig. 2d and e).

\section{Anticoagulant activity}

Some carbohydrates have anticoagulant impacts by repressing thrombin or by initiating against thrombin III or by expanding the coagulating time. Additionally, these molecules can likewise have an antithrombotic action by blocking thrombin movement, interceded through the heparin cofactor II (Li et al. 2012; De Jesus Raposo et al. 2015).

Yet, different researchers prove that they likewise interfere in the prothrombin (PT) pathway, and hence, are not ready to influence the outward coagulation pathway (Nishino et al. 1989; Silva et al. 2010; Wijesekara et al. 2011; Cao et al. 2019). Besides, a critical job of the substance in sulfate has been assigned in the anticoagulant activities, as the nearness of sulfate and its circulation design assume a vital job in the procedures of coagulation (Fig. 3).

\section{Multifunctional pharmaceutical excipients for marine polysaccharides}

A medication-infused intravascularly specifically enters the blood and creates its pharmacological impacts. The

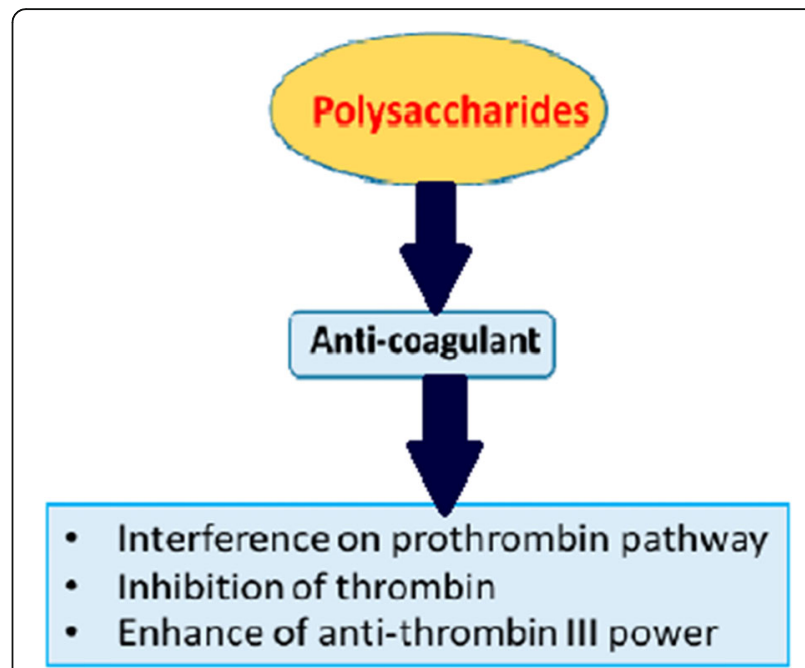

Fig. 3 Mechanism of anticoagulant activity of marine polysaccharides

larger parts of medications are controlled extravascularly, more often than not through oral course. Such medications can create their pharmacological activities just when they come into the blood circulation from their site of application. So as to achieve the blood circulation, orally-managed plan must break down, deaggregate, and disintegration of the medication in the watery liquid at the ingestion site must happen. If the medications are not hydrophilic in nature, the retention procedure of medications like these is normally disintegration rate constrained. Better absorption can be accomplished by adjusting the attributes of the measurement shape utilizing pharmaceutical excipients. Additionally, pharmaceutical excipients help in the assembling procedure by serving as binder, diluents, wetting agent, filling agent, disintegrating agents, dissolution enhancers, etc. (Fig. 4a) (Saravanan et al. 2003; Laurienzo 2010; Dhanaraju et al. 2011).

\section{As binder}

EPS from marine bacteria can fill in as decent binders in the creation of tablets by the wet granulation technique for fabricate. In this job, binders are either included as a solution or as a solid into the powder mix (following which the granulating liquid, commonly water, is included). Because of the high centralization of hydroxyl bunches in the polysaccharide, for the most part have a high water-restricting limit that makes wet granulation less demanding (Paolucci et al. 2015).

\section{As diluents}

Bacterial marine EPS can be utilized as diluents/fillers in the form of tablets (by all strategies) to build the mass of the strong measurement frames that hold a low centralization of therapeutic agent and thereby render 


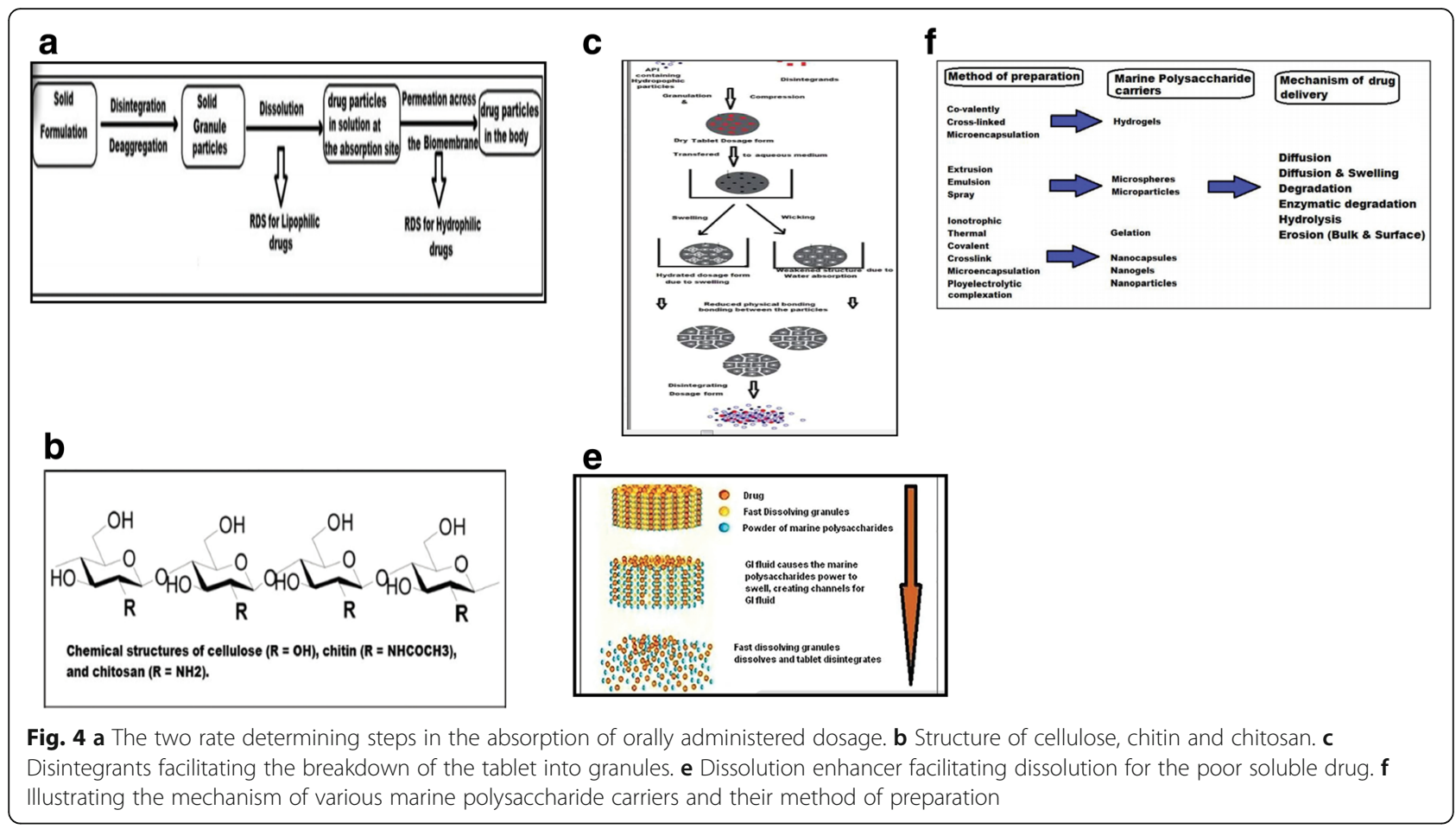

the assembling procedure increasingly solid and reproducible (De Jesus Raposo et al. 2015). For instance, chitin and chitosan are utilized as a diluent or filler and as a binder in direct pressure of tablet preparing, as a disintegrant, etc. Chitin and chitosan have a least mass and tapped thickness that reason great stream and compaction during filling and tablet pressure handling. Figure $4 \mathrm{~b}$ demonstrates the structure of cellulose chitin and chitosan.

\section{As disintegrants}

Disintegrants are materials added to the dose shapes that improve the separation or deterioration of tablet plans into littler particles that break up quicker than without disintegrants. These materials have the fundamental job to restrict the productivity of tablet binder and physical powers that act under pressure to shape the tablets. Tablet disintegrant of 132 biological activities and utilization of marine EPS are typically considered as the rate determining advance (RDS) in a quicker medication release. Marine bacterial EPS may act as a decent deteriorating operator by expanding the porosity, wettability, and wicking or slender activity and work by swelling within the sight of watery liquids in tablet definitions to encourage the breakdown of the tablet into granules upon section into the stomach (Thomas and Kim 2013) (Fig. 4c).

\section{As dissolution enhancers}

Bacterial EPSs from marine may fill in as a disintegration enhancer for the poor dissolvable medication (Hoare and Kohane 2008). These powders can decrease firm powers holding a tablet measurement shape together and incite the separation into littler granules, consequently expanding the viable surface region for disintegration (Fig. 4d).

\section{As drug delivery carriers}

Marine EPS have been generally used to synthesize drug delivery carriers. They are bio-perfect, non-dangerous, and bio-degradable and upgrades response that makes marine EPS fitting hotspots for the building of complex loading devices with a discharge that can be viably controlled (Dhanaraju et al. 2011). Drug delivery devices can be developed utilizing different techniques and can be orchestrated in an assortment of shapes, for example, hydro gels, smaller scale or nanoparticles, and capsules, fit for ensuring an assortment of bioactive operators, for example, proteins and nucleic acids (Fig. 4e).

\section{Conclusion}

Microorganisms play an important role in the recycling of elements and ecological balance, especially in the marine environment (oceans and seas) that occupies the largest area of land. EPS produced by these microorganisms are one of the most important secretions responsible for survival in the marine environment through different strategies such as storing food, forming biofilms, and acting as a dispersion agent during hunger. Polysaccharide is also a major player in carbon sequestration and the stability of metal ions through the socalled biological pump responsible for assembling small 
particles of the surface, which causes them to sink to the bottom. The secretions of microorganisms (especially external polysaccharides) are the masterminds of this pump. On the other hand, these secretions provide a renewable range of materials used in industrial and pharmaceutical applications. Therefore, EPS can be applied in a wide range of industrial applications in biomedicines as antibacterial, antifungal, antioxidant, antitumor, anti-inflammatory, and antiviral.

\section{Recommendations and future works}

1. The fed-batch and continuous of marine bacteria which produced exopolymers using pilot-scale fermentor should be carried out in future.

2. Using molecular biology study to increase the exopolymers

3. Search for other new medical application of exopolymers produced by marine bacteria

\section{Abbreviations}

EPS: Exopolysaccharides; CPS: Capsular polysaccharide; MDR: Multi-drug resistance; ROS: Reactive oxygen species; LAB: Lactic acid bacteria; ALL: Acute lymphoblastic leukemia; TGF: Transforming growth factor; CPE: Cytopathic impact; HSV: Herpes simplex infection; PBMC: Peripheral blood mononuclear cells; PT: Prothrombin

\section{Acknowledgements}

National Research Centre

\section{Authors' contributions}

All the participant researchers contributed to do this work; Dr. Saher collected the material and wrote the review; Dr. Manal also wrote the review and revised this review; Sayeda formatted the review and sent to the Journal. The author(s) read and approved the final manuscript.

\section{Funding}

All funding from National Research Centre

\section{Availability of data and materials}

All data and material available

\section{Ethics approval and consent to participate}

Not applicable

\section{Consent for publication}

All the participant researchers consented for the publication.

\section{Competing interests}

The authors declare that they have no competing interests.

Received: 29 October 2019 Accepted: 14 April 2020

Published online: 05 May 2020

\section{References}

Abad M, Bedoya LM, Bermejo P (2011) Marine compounds and their antimicrobial activities. Science Against Microbial Pathogens:1293-1306

Abas F, Lajis N, Israf D, Khozirah Y, Umi KY (2006) Antioxidant and nitric oxide inhibition activities of selected Malay traditional vegetables. Food Chem 95 : 566-573

Aceves C, Anguiano B, Delgado G (2005) Is iodine a gatekeeper of the integrity of the mammary gland? J Mammary Gland Biol Neoplasia 10:189-196

Adhikaria U, Mateub CG, Chattopadhyaya KC, Pujolb A, Damonteb EB, Ray B (2006) Structure and antiviral activity of sulfated fucans from Stoechospermum marginatum. Phytochemistry 67:2474-2482
Aguilar C, Vlamakis H, Losick R, Kolter R (2007) Thinking about Bacillus subtilis as a multicellular organism. Curr Opin Microbiol 10:638-643

Ahmad S (1995) Antioxidant mechanisms of enzymes and proteins. In: Ahmad S (ed) Oxidative stress and antioxidant defense in Biology. Chapman and Hall, Inc., New York, pp 238-272

Allen TM (2002) Ligand targeted therapeutics in anticancer therapy. Nat Rev Cancer 2:750-763

Arad SM, Ginsberg A, Huleihel M (2006) In: Fingerman M, Nagabhusan R editors, Biomaterials from aquatic and terrestrial organizations. Enfield $(\mathrm{NH})$ : Science Publishers 37-62

Arena A, Gugliandolo C, Stassi G, Pavone B, lannello D, Bisignano G, Maugeri TL (2009) An exopolysaccharide produced by Geobacillus thermodenitrificans strain B3-72: antiviral activity on immunocompetent cells. Immunol Letters 123:132-137

Arias S, del Moral A, Ferrer MR, Tallon R, Quesada E, Béjar V (2003) Mauran, an exopolysaccharide produced by the halophilic bacterium Halomonas maura, with a novel composition and interesting properties for biotechnology. Extremophiles 7(4):319-326

Asker MMS, Shawky BT (2010) Structural characterization and antioxidant activity of an extracellular polysaccharide isolated from Brevibacterium otitidis BTS 44. Food Chem 123(2):315-320

Asker MS, Ibrahim AY, Mahmoud MG, Mohamed SS (2015) Production and characterization of exopolysaccharide from novel Bacillus sp. M3 and evaluation on development sub-chronic aluminum toxicity induced Alzheimer's disease in male rats. Am J Biochem Biotechnol 11 (2): 92.103.

Berge JP, Debiton E, Dumay J, Durand P, Barthomeuf C (2002) In vitro antiinflammatory and anti-proliferative activity of sulfolipids from the red algae Prophyridium cruentum. J Agri Food Chem 5:6227-6232

Biffi A, Coradini D, Larsen R, Riva L, Di Fronzo G (1997) Antiproliferative effect of fermented milk on the growth of a human breast cancer cell line. Nutr Cancer 28:93-99

Blander GR, De Oliveira M, Conboy CM, Haigis M, Guarente L (2003) Superoxide dismutase 1 knock-down induces senescence in human fibroblasts. J Biol Chem 278(40):38966-38969

Borchers AT, Stern JS, Hackman RM (1999) Mushrooms, tumors, and immunity. Soc Exp Biol Med 221:281-293

Braissant O, Decho AW, Przekop KM, Gallagher KL, Glunk C, Dupraz C, Visscher PT (2009) Characteristics and turnover of exopolymeric substances in a hypersaline microbial mat. FEMS Microbiol Ecol 67:293-307

Cao S, He X, Qin L, He M, Yang Y, Liu Z, Mao W (2019) Anticoagulant and antithrombotic properties in vitro and in vivo of a novel sulfated polysaccharide from marine green alga Monostroma nitidum. Mar Drugs 17: 247-268

Chen Y, Mao W, Tao H, Zhu W, Qi X, Chen Y, Li H, Zhao C, Yang Y, Hou Y, Wang C, Li N (2011) Structural characterization and antioxidant properties of an exopolysaccharide produced by the mangrove endophytic fungus Aspergillus sp. Y16. Bioresource Technol 102:8179-8184

Damonte EB, Matulewicz MC, Cerezo AS (2004) Sulfated seaweed polysaccharides as antiviral agents. Cur Med Chem 18:2399-2419

Davies KJ (2000) Oxidative stress, antioxidant defenses and damage removal, repair, and replacement systems. lubmb Life 50:279-289

De Clercq E (2004) Antiviral drugs in current chemical reviews. J Clin Virol 30: 115-133

De Jesus Raposo MF, de Morais AMB, de Morais R MSC (2014) Bioactivity and applications of polysaccharides from marine microalgae. In Polysaccharides: Bioactivity and Biotechnology; Merillon, J.-M., Ramawat, K.G., Eds.; Springer: Cham, Switzerland.

De Jesus Raposo MF, de Morais AMB, de Morais RMSC (2015) Marine polysaccharides from algae with potential biomedical applications. Marine Drugs 13(5):2967-3028

De Vugst L, Vandamme EJ (1994) Bacteriocins of lactic acid bacteria. Microbiol Genet Appl, London: Blackie Acadamic and Profession, vol. 75, pp. 140174 140179.

De Vuyst L, Degeest B (1999) Hetero polysaccharides from lactic acid bacteria. FEMS Microbiol Rev 23(2):153-177

Delbarre-Ladrat C, Sinquin C, Lebellenger L, Zykwinska A, Colliec-Jouault S (2014) Exopolysaccharides produced by marine bacteria and their applications as glycosaminoglycans-like molecules. Front Chem 2:85

Devesh P, Rahul J, Mukesh P (2017) Marine bacterial extracellular polysaccharides: a review. J Coastal Life Med 5(1):29-35 
Dhanaraju MD, Elisabeth S, Thirumurugan G (2011) Triamcinolone-loaded glutaraldehyde cross-linked chitosan microspheres: prolonged release approach for the treatment of rheumatoid arthritis. Drug Delivery 18(3):198207

Diao Y, Xin Y, Zhou Y, Li N, Pan X (2014) Extracellular polysaccharide from Bacillus sp. strain LBP32 prevents LPS-induced inflammation in RAW 264.7 macrophages by inhibiting NF-KB and MAPKs activation and ROS production. Int Immunopharmacol 18:12-19

Dias PF, Siqueira JM, Maraschin M, Ferreira AG, Gagliardi AR, Ribeirodo-Valle RM (2008) A polysaccharide isolated from the brown seaweed Sargassum stenophyllum exerts antivasculogenic effects evidenced by modified morphogenesis. Microvasc Res 75(1):34-44

Donato PD, Poli A, Taurisano V, Abbamondi GR, Nicolaus B, Tommonaro G (2016) Recent advances in the study of marine microbial biofilm: from the involvement of quorum sensing in its production up to biotechnological application of the polysaccharide fractions. J Mar Sci Eng 4(34):1-14

Dreosti IE (1991) Trace elements, micronutrients, and free radicals. Human Press, Totowa, pp 149-199

Dupraz C, Visscher PT (2005) Microbial lithification in marine stromatolites and hypersaline mats. Trends Microbiol 13:429-438

Elsakhawy TA, Fatma AS, Abd-EL-Kodoos RY (2017) Marine microbial polysaccharides: environmental role and applications (an overview). Env. Biodiv. Soil Security 1:61-70

Eskin BA, Grotkowski CE, Connolly CP (1995) Different tissue responses for iodine and iodine in rat thyroid and mammary glands. Biological. Trace Element Research 49:9-19

Ferlay J, Shin HR, Bray F, Orman D, Mathers C, Parkin DM (2010) Estimates of worldwide burden of cancer in 2008. Int J Cancer 127:2893-2917

Flemming HC, Leis A, Wingender J (2004) Biofilm and the role of extracellular polymeric substance. Advances in biofilm science and engineering (Ryan RJJ, Williams DM \& Charaf U, eds), pp. 86-142.

Fuller R (1989) Probiotics in man and animal. J Appl Bacteriol 66:365-378

Funahashi H, Imai T, Mase T, Sekiya M, Yokoi K, Hayashi H (2001) Seaweed prevents breast cancer. Jap J Cancer Res 92(5):483-487

Gey KF (1990) The antioxidant hypothesis of cardiovascular disease: epidemiology and mechanisms. Biochem Soc Trans 18:1041-1045

Ginsberg RH, Goebel WF, Horsfall FL (1947) Inhibition of mumps virus multiplication by a polysaccharide. Proc Soc ExpBiol Med 66:99-100

Goldin BR, Gorbach SL (1992) Probiotics for humans In Probiotics, R. Fuller, Ed., pp. 355-376, Chapman and Hall, London, UK

Guezennec J (2002) Deep-sea hydrothermal vents: a new source of innovative bacterial exopolysaccharides of biotechnological interest. J Ind Microbiol Biotechnol 29:204-208

Haefner B (2003) Drugs from the deep: marine natural products as drug candidates. Drug Discovery Today 8(12):536-544

Han F, Yao WB, Yang XB, Liu XN, Gao XD (2005) Experimental study on anticoagulant and antiplatelet aggregation activity of a chemically sulfated marine polysaccharide YCP. Int J Biol Macromol 36(4):201-207

Hayashi K, Nakano T, Hashimoto M, Kanekiyo K, Hayashi T (2008) Defensive effects of a fucoidan from brown alga Undaria pinnatifida against herpes simplex virus infection. Int. Immunopharmacol 8:109-116

He F, Yang Y, Yang G, Yu L (2010) Studies on antibacterial activity and antibacterial mechanism of a novel polysaccharide from Streptomyces virginia H03. Food Control 21(9):1257-1262

Hemmingson JA, Falshaw R, Furneaux RH, Thompson K (2006) Structure and antiviral activity of the galactofucan sulfates extracted from Undaria pinnatifida (Phaeophyta). J Appl Phycol 18:185-193

Hoare TR, Kohane DS (2008) Hydrogels in drug delivery: progress and challenges. Polymer 49:1993-2007

Hobbs C (2000) Medicinal value of Lentinus edodes (Berk.) Sing. (Agaricomycetideae). a literature review. International J. Med Mushrooms 2: 287-302

Hu JF, Gen MY, Zhang JT, Jiang HD (2001) An in vitro study of the structureactivity relationships of sulfated polysaccharide from brown algae to its antioxidant effect. J Asian Nat Prod Res 3(4):353-358

Hu TD, Liu Y, Chen J, Wu WS (2010) Antioxidant activity of sulfated polysaccharide fractions extracted from Undaria pinnitafida in vitro. Int J Bio Macromol 46(2):193-198

Hu XQ, Huang YY, Dong QF, Song LY, Yuan F, Yu RM (2011) Structure characterization and antioxidant activity of a novel polysaccharide isolated from pulp tissues of Litchi chinensis. J Agric Food Chem 59(21):11548-11552
IARC (2010) International Agency for Research on Cancer: Cancer incidence and mortality worldwide. IARC, Lyon, France

Ikewa T (2001) Beneficial effects of edible and medicinal mushrooms in health care. Int J med Mushrooms 3:291-298

Itoh H, Noda H, Amano H, Ito H (1995) Immunological analysis of inhibition of lung metastases by fucoidan (GIVA) prepared from brown seaweed Sargassum thunbergii. Anticancer Res 15(5):1937-1947

Iwai K, Kishimoto N, Kakino Y, Mochida K, Fujita T (2004) In vitro antioxidative effects and tyrosinase inhibitory activities of seven hydroxycinnamoyl derivatives in green coffee beans. J Agric Food Chem 52:4893-4898

Jemal A, Bray F, Center MM, Ferlay J, Ward E, Forman D (2011) Global cancer statistics. CA Cancer J Clin 61(2):69-90

Jin ML, Wang YM, Xu CL, Lu ZQ, Huang M, Wang YZ (2010) Preparation and boil activities of an exopolysaccharide produced by Enterobacter cloacae Z0206. Carbohydr Polym 81:607-611

John M (2002) Natural products in cancer chemotherapy: past, present and future. Nature Reviews Cancer 2:143-148

Kambourova M, Mandeva R, Dimova D, Poli A, Nicolaus B, Tommonaro G (2009) Production and characterization of a microbial glucan, synthesized by Geobacillus tepidamans V264 isolated from Bulgarian hot spring. Carbohydr Polym 77:338-343

Katalinic V, Milos M, Kulisic T, Jukic M (2006) Screening of 70 medicinal plant extracts for antioxidant capacity and total phenols. Food Chem 94:550-557

Kathiresan K, Duraisamy K (2005) Current issue of microbiology. Envis Centre News letters 4:3-5

Kathiresan K, Thiruneelakandan G (2008) Prospects of lactic acid bacteria of marine origin. Indian J Biotechnol 7(2):170-177

Kato I, Endo K, Yokokura T (1994) Effects of oral administration of Lactobacillus casei on antitumor responses induced by tumor resection in mice. Int J Immunopharmacol 16:29-36

Ke C, Qiao D, Gan D, Sun Y, Ye H, Zeng X (2009) Antioxidant activity in vitro and in vivo of the capsule polysaccharides from Streptococcus equi subsp. zooepidemicus. Carbohydr Polym 75(4):677-682

Kinghorn G (2001) Asexual health and HIV strategy for England: this ambitious strategy could, if properly resourced, greatly improve sexual health. BMJ 323(7307):243-244

Kleymann G (2005) Agents and strategies in development for improved management of herpes simplex virus infection and disease. Expert Opin Investig Drugs 14:135-161

Kodali VP, Sen R (2008) Antioxidant and free radical scavenging activities of an exopolysaccharide from a probiotic bacterium. Biotechno J 3(2):245-251

Kwon MJ, Nam TJ (2006) Porphyran induces apoptosis related signal pathway in AGS gastric cancer cell lines. Life Science 79:1956-1962

Langseth L (1995) Oxidants, antioxidants, and disease prevention, International Life Sciences Institute Press, Washington, DC, USA.

Laurienzo P (2010) Marine polysaccharides in pharmaceutical applications: an overview. Mar Drugs 8:2435-2465

Laws A, Gu Y, Marshall V (2001) Biosynthesis, characterization, and design of bacterial exopolysaccharide from lactic acid bacteria. Biotechnol Advances 19(8):597-625

Lee HK, Chun J, Moon EY, Ko SH, Lee DS (2001) An extracellular-polysaccharideproducing marine bacterium. International J. Systematic Evolutionary Microbiol 2:661-666

Lee JB, Hayashi K, Hashimoto M, Nakano T, Hayashi T (2004) Novel antiviral fucoidan from sporophyll of Undaria pinnatifida (Mekabu). Chem Pharm Bull 52:1091-1094

Li F, Tian TC, Shi YC (1995) Study on antivirus effect of fucoidan in vitro. J N Bethune Univ Med Sci 21:255-257

Li H, Mao W, Hou Y, Gao Y, Qi X, Zhao C, Chen Y, Chen Y, Li N, Wang C (2012) Preparation, structure and anticoagulant activity of a low molecular weight fraction produced by mild acid hydrolysis of sulfated rhamnan from Monostroma latissimum. Bioresour Technol 114:414-418

Liu F, Ooi VE, Chang ST (1997) Free radical scavenging activities of mushroom polysaccharide extracts. Life Sci 60:763-771

Liu J, Luo J, Ye H, Sun Y, Lu Z, Zeng X (2009) Production, characterization and antioxidant activities in vitro of exopolysaccharides from entophytic bacterium Paenibacillus polymyxa EJS-3. Carbohydr Polym 78:275-281

Liu JM, Bignon J, Haroun-Bouhedja F, Bittoun P, Vassy J, Fermandjian S, Wdzieczak-Bakala J, Boisson-Vidal C (2005) Inhibitory effect of fucoidan on the adhesion of adenocarcinoma cells to fibronectin. Anticancer Res 25: 2129-2133 
Looijesteijn PJ, Trapet L, De Vries E, Abee T, Hugenholtz J (2001) Physiological function of exopolysaccharides produced by Lactococcus lactis. Int J Food Microbiol 64:71-80

Lu R, Yoshida T, Nakashima H, Premanathan M, Aragaki R, Mimura T, Kaneko Y YN Miyakoshi T, Uryu M (2000) Specific biological activities of Chinese lacquer polysaccharides. Carbohydr Polym 43:47-54

Luescher-Mattli M (2003) Algae, a possible source for newdrugs in the treatment of HIV and other viral diseases. Anti-Infective Agents Cur Med Chem 2(3): 219-225

Macfarlane GT, Cummings JH (2002) Probiotics, infection and immunity. Curr Opin Infect Dis 15:501-506

Mandal P, Mateu CG, Chattopadhyay K, Pujol CA, Damonte EB, Ray B (2007) Structural features and antiviral activity of sulphated fucans from the brown seaweed Cystoseira indica. Antivir Chem Chemother 18:153-162

Markova N, Kussovski V, Drandarska I, Nikolaeva S, Georgieva N, Radoucheva T (2003) Protective activity of Lentinan in experimental tuberculosis. Int Immunopharmacol 3:1557-1562

Markova N, Michailova L, Kussovski V, Jourdanova M, Radoucheva T (2005) Intranasal application of Lentinan enhances bactericidal activity of rat alveolar macrophages against Mycobacterium tuberculosis. Pharmazie 60:42-48

Martins A, Vieira H, Gaspar H, Santos H, Gaspar H (2014) Marketed marine natural products in the pharmaceutical and cosmeceutical industries: Tips for success. Mar Drugs 12:1066-1101

Masuda T, Yonemori S, Oyama Y, Takeda Y, Tanaka T, Andoh T, Shinohara A, Nakata M (1999) Evaluation of the antioxidant activity of environmental plants: activity of the leaf extracts from seashore plants. J Agric Food Chem 47(4):1749-1754

Matsuda M, Yamori T, Naitoh M, Okutani K (2003) Structural revision of sulfated polysaccharide B-1 isolated from a marine Pseudomonas species and its cytotoxic activity against human cancer cell lines. Marine Biotechnol 5(1):13-19

Mau JL, Lin HC, Chen CC (2002) Antioxidant properties of several medicinal mushrooms. J Agric Food Chem 50(21):6072-6077

Mayer AMS, Lehmann VKB (2004) Marine compounds with antibacterial, anticoagulant, antifungal, antiinflammatory, anthelmintic, antiplatelet, antiprotozoal and antiviral activities; with actions on the cardiovascular, endocrine, immune and nervous systems: and other miscellaneous mechanisms of action. Pharmacol 42:62-69

McReynolds KD, Garvey-Hague J (2007) Chemotherapeutic interventions targeting HIV interactions with host associated carbohydrates. Chem Rev 107:1533-1552

Meera CR, Syama C, Rakhi J, Wilsy W, Anjana JC, Ruveena TN (2011) Antimicrobial and anti-oxidant activities of polysaccharides isolated from an edible mushroom, Pleurotus florida. Bio Tech 10(08):12-13

Miller AB, Hoogstraten B, Staquet M, Winkler A (1981) Reporting results of cancer treatment. Cancer 47:207-214

Miranda CA, Martins OB, Clementino MM (2008) Species-level identification of Bacillus strains isolates from marine sediments by conventional biochemical, 16SrRNA gene sequencing and inter-tRNA gene sequence lengths analysis. Antonie Van Leeuwenhoek 93:297-304

Moradali MF, Mostafavi H, Ghods S, Hedjaroude GA (2007) Immunomodulating and anticancer agents in the realm of macromycetes fungi (macrofungi). Inter Immunopharma 7:701-724

Moskovitz J, Yim MB, Chock PB (2002) Free radicals and disease. Arch Biochem. Biophys 397:354-359

Nadia R, Susan C, Stefano G, Maria C1 (2016) Polysaccharides from the marine environment with pharmacological, cosmeceutical and nutraceutical potential. Molecules 21(551): 1-16.

Nahmias AJ, Kibrick S (1964) Inhibitory effect of heparin on herpes simplex virus. J Bacteriol 87:1060-1066

Nguyen VT, Gidley MJ, Dykes GA (2008) Potential of a nisin-containing bacterial cellulose film to inhibit Listeria monocytogenes on processed meats. Food Microbiol 25(3):471-478

Nishino T, Yokoyama G, Dobahi K (1989) Isolation, purification and characterization of fucose-containing sulfated polysaccharides from the brown seaweed Ecklonia kurome and their blood-anticoagulant activities. Carbohydr Res 186:119-129

Oberley TD (2002) Oxidative damage and cancer. Am J Pathol 160:403-408

Ohno N, Furukawa M, Miura NN, Adachi Y, Motoi M, Yadomae T (2001) Antitumor $\beta$-glucan from the cultured fruit body of Agaricus blazei. Biological Pharm Bull 24:820-828
Oliveira BF, Nogueira-Machado JA, Chaves MM (2010) The role of oxidative stress in the aging process. Sci World J 10:1121-1128

Ooi VEC, Liu F (1999) A review of pharmacological activities of mushroom polysaccharides. Int J Med Mush 1:195-206

Ooi VEC, Liu F (2000) Immunomodulation and anticancer activity of polysaccharide-protein complexes. Curr Med Chem 7(7):715-729

Orsod M, Joseph M, Huyop F (2012) Characterization of exopolysaccharides produced by Bacillus cereus and Brachybacterium sp. isolated from Asian Sea Bass (Lates calcarifer). Malaysian J Microbiol 8(3):170-174

Pang X, Chen Z, Gao X, Liu W, Slavin M, Yao W, Yu LL (2007) Potential of a novel polysaccharide preparation (GLPP) from anhui-grown Ganoderma lucidum in tumor treatment and immunostimulation. J Food Sci 72(6):5435-5442

Pangestuti R, Kim SK (2011) Neuroprotective effects of marine algae. Mar Drugs 9 : 803-818

Paolucci M, Fasulo G, Volpe MG (2015) Employment of marine polysaccharides to manufacture functional biocomposites for aquaculture feeding applications. Marine Drugs 13(5):2680-2693

Pilar J, Jose C, Ramon VC (2005) Fucoidans from the brown seaweed Adenocystis utricularis: extraction methods, antiviral activity and structural studies. Carbohydr Res 338:153-165

Poli A, Anzelmo G, Nicolaus B (2010) Bacterial exopolysaccharides from extreme marine habitats: production, characterization, and biological activities. Mar Drugs 8(6):1779-1802

Ponce NMA, Pujol CA, Damonte EB (2003) Fucoidans from the brown seaweed Adenocystis utricularis: extraction methods, antiviral activity and structural studies. Carbohydr. Res 338:153-165

Raguenes G, Christen R, Guezennec J, Pignet P, Barbier G (1997) A new polysaccharide-secreting organism isolated from a deep-sea hydrothermal vent polychaete annelid, Alvinella pompejana. Int I Syst Bacteriol 47:989-995

Raza W, Makeen K, Wang Y, Xu Y, Qirong S (2011) Optimization, purification, characterization and antioxidant activity of an extracellular polysaccharide produced by Paenibacillus polymyxa SQR-21. Bioresource technol 102(10): 6095-6103

Reddy BS, Sharma C, Mathews L (1984) Effect of Japanese seaweed (Laminaria angustata) extracts on the mutagenicity of 7, 12-dimethylbenz[a] anthracene, a breast carcinogen, and of 3, 2'-dimethyl-4-aminobiphenyl, a colon and breast carcinogen. Mutat Res 127(2):113-118

Roberts IS (1996) The biochemistry and genetics of capsular polysaccharide production in bacteria. Ann Rev Microbiol 50:285-315

Rougeaux H, Kervarec N, Pichon R, Guezennec J (1999) Structure of the exopolysaccharide of Vibrio diabolicus isolated from a deep-sea hydrothermal vent. Carbohydr Res 322:40-45

Ruiz-Ruiz C, Srivastava GK, Carranza D, Mata JA, Llamas I, Santamaría M, Quesada E, Molina IJ (2011) An exopolysaccharide produced by the novel halophilic bacterium Halomonas stenophila strain B100 selectively induces apoptosis in human T leukaemia cells. Applied Microbiol Biotechn 89:345-355

Salgaller ML, Lodge PA (1998) Use of cellular and cytokine adjuvants in the immunotherapy of cancer. J Surg Oncol 68(2):122-138

Sangeetha P, Das UN, Koratkar R, Suryaprabha P (1990) Increase in free radical generation and lipid peroxidation following chemotherapy in patients with cancer. Free Radic Biol Med 8(1):15-19

Saravanan M, Bhaskar K, Srinivasa RG, Dhanaraju MD (2003) Ibuprofen-loaded ethylcellulose/polystyrene microspheres: an approach to get prolonged drug release with reduced burst effect and low ethylcellulose content. J Microencaps: Micro and Nano Carriers 20(3):289-302

Satoru K, Noboru T, Hiroo N, Shinji S, Hiroshi S (2003) Oversulfation of fucoidan enhances is anti-angiogenic and antitumor activities. Biochemica Pharmacology 65:173-179

Selim MS, Amer SK, Mohamed SS, Mounier MM, Rifaat HM (2018a) Production and characterisation of exopolysaccharide from Streptomyces carpaticus isolated from marine sediments in Egypt and its effect on breast and colon cell lines. J Genetic Eng Biotechnol 16(1):23-28

Selim MS, Mohamed SS, Asker MM, Salama AAA, Abdallah HMI, Yassen NN (2018b) Production and characterization of exopolysaccharide from marine Bacillus sp. MSHN2016 with studying its effect on isoniazid/ rifampicininduced hepatic and renal toxicities in rats. J Appl Pharm Sci 8(08):1-11

Selim MS, Mohamed SS, Shimaa RH, El Sayed OH (2015) Screening of bacterial antioxidant exopolysaccharides isolated from Egyptian habitats. J Chem Pharm Res 7(4):980-986

Senel S, McClure SJ (2004) Potential applications of chitosan in veterinary medicine. Adv Drug Deliv Rev 56:1467-1480 
Seng YH, Yang JH, Mau JL (2008) Antioxidant properties of polysaccharides from Ganoderma tsugae. Food Chem 107(2):732-738

Shanmugam A, Mahalakshmi TS, Barwin Vino A (2008) Antimicrobial activity of polysaccharide isolated from the cuttlebone of sepia aculeata and Sepia brevimana: an approach to selected antimicrobial activity for human pathogenic microorganisms. J Fisher Aqua Sci 3:268-274

Shibata M, Katoh H, Sonoda M, Ohkawa H, Shimoyama M, Fukuzawa H, Kaplan A, Ogawa T (2002) Genes essential to sodium-dependent bicarbonate transport in cyanobacteria. Function and phylogenetic analysis. J Biol Chem 277: 18658-18664

Silva FRF, Dore CMPG, Marques CT, NascimentoMS BNMB, Rocha HAO, Chavante SF, Leite EL (2010) Anticoagulant activity, paw edema and pleurisy induced carrageenan: action of major types of commercial carrageenans. Carbohydr Polym 79:26-33

Sutherland IW (1972) Bacterial exopolysaccharides. Adv Microb Physiol 8:143-213

Thomas NV, Kim SK (2013) Beneficial effects of marine algal compounds in cosmeceuticals. Marine Drugs 11(1):146-164

Tiwari AK (2001) Imbalance in antioxidant defense and human diseases: multiple approach of natural antioxidant therapy. Curr Sci 8:1179-1187

Umezawa H, Okami Y, Kurasawa S, Ohnuki T, Ishizuka M (1983) Marinactan, antitumor polysaccharide produced by marine bacteria. J Antibiot 36(5): 471-477

Wang C, Fan Q, Zhang X, Lu X, Xu Y, Zhu W, Jie ZJ, Hao W, Hao L (2018) Isolation, characterization, and pharmaceutical applications of an exopolysaccharide from Aerococcus Uriaeequi. Mar Drugs 16:337

Wasser SP (2002) Medicinal mushrooms as a source of antitumor and immunomodulating polysaccharides. App Microbiol Biotechnol 60:258-274

Wasser SP, Weis AL (1999) Therapeutic effects of substances occurring in higher basidiomycetes mushrooms: a modem perspective. Critical Rev Immun 19:65-96

Wei DL, Bo DZ, Wei R, Ji LL, Zhi LL (2008) Reversal effect of Ganoderma lucidum polysaccharide on multi drug resistance in K562/ADM cell line. Acta Pharmacol Sin 29(5):620-627

Whitfield C (1988) Bacterial extracellular polysaccharides. Can J Microbiol 34:415420

Wijesekara I, Pangestuti R, Kim SK (2011) Biological activities and potential health benefits of sulfated polysaccharides derived from marine algae. Carbohydr Polym 84:14-21

Witvrouw M, De Clercq E (1997) Sulfated polysaccharides extracted from sea algae as potential antiviral drugs. Gen Pharmacol 29:497-511

Wollowski I, Rechkemmer G, Pool-Zobel BL (2001) Protective role of probiotics and prebiotics in colon cancer. Am J Clin Nutr 73(2):451-455

Wu XZ, Chen D (2006) Effects of sulfated polysaccharides on tumor biology. West Indian Med J 55(4):270-273

Xu CL, Wang YZ, Jin ML, Yang XQ (2009) Preparation, characterization and immunomodulatory activity of selenium-enriched exopolysaccharide produced by bacterium Enterobacter cloacae Z0206. Bioresource Technol 100: 2095-2097

Xu R, Shen Q, Ding X, Gao W, Li P (2011) Chemical characterization and antioxidant activity of an exopolysaccharide fraction isolated from Bifidobacterium animalis RH. Eur Food Res Technol. 23:231-240

Yahya SMM, Abdelnasser SM, Hamed AR, El Sayed OH, Asker MS (2019) Newly isolated marine bacterial exopolysaccharides enhance antitumor activity in HepG2 cells via affecting key apoptotic factors and activating toll like receptors. Mol Biol Reports 46:6231-6241

Yamasaki MY, Yamasaki M, Tachibana H, Yamada K (2009) Fucoidan induces apoptosis through activation of caspase-8 on human breast cancer MCF-7 Cells. J Agric Food Chem 57:8677-8682

Yamasaki Y, Yamasaki M, Achibana $H$, Yamada $H$ (2012) Important role of $\beta_{1}$ integrin in fucoidan-induced apoptosis via caspase-8 activation. Biosci Biotechnol Biochem 76(6):1163-1168

Yan W, Zhang H, Yu H, Wang X (2010) New polysaccharide compounds derived from submerged culture of Ganoderma lucidum and Lycium barbarum. Food Technol Biotechnol 48:94-101

Yan Y, Yu C, Chen J, Li X, Wang W, Li S (2011) Ultrasonic-assisted extraction optimized by response surface methodology, chemical composition and antioxidant activity of polysaccharides from Tremella mesenterica. Carbohydr Polym 83(1):217-224

Yang CS, Landau JM, Huang MT, Newmark HL (2001) Inhibition of carcinogenesis by dietary polyphenolic compounds. Annu Rev Nutr 2:381-406
Ye J, Li Y, Teruya K, Katakura Y, Ichikawa A, Eto H (2005) Enzyme-digested fucoidan extracts derived from seaweed Mozuku of Cladosophon novaecaledoniaekylin inhibit invasion and angiogenesis of tumor cells. Cytotechnology 47:1-3

Ye LB, Zhang JS, Yang Y, Zhou S, Liu YF, Tang QJ, Du XJ, Chen H, Pan YJ (2009) Structural characterization of a heteropolysaccharide by NMR spectra. Food Chem 112(4):962-966

Yumi Y, Masao Y, Hirofumi T, Koji Y (2009) Fucoidan induces apoptosis through activation of caspase-8 on human breast cancer MCF-7 cells. J Agri Food Chem 57:8677-8682

Zhang HN, He JH, Yuan L, Lin ZB (2003) In vitro and in vivo protective effect of Ganoderma lucidum polysaccharides on alloxan-induced pancreatic islets damage. Life Sci 73(18):2307-2319

Zhang M, Ren Q, Chen Y (2002) Studies on the antitumor effect of glycoproteins from Enterobacter cloacae. J Fudan Univ 41:378-381

\section{Publisher's Note}

Springer Nature remains neutral with regard to jurisdictional claims in published maps and institutional affiliations.

\section{Submit your manuscript to a SpringerOpen ${ }^{\circ}$ journal and benefit from:}

- Convenient online submission

- Rigorous peer review

- Open access: articles freely available online

- High visibility within the field

- Retaining the copyright to your article

Submit your next manuscript at $>$ springeropen.com 